\title{
EFFECT OF SOME AGRICULTURAL PRACTICES ON IMPROVING SALTS AFFECTED SANDY SOIL PRODUCTIVITY
}

\author{
Hoda $^{\star}$ A. Elia and Boulos D.S.M. \\ Chemistry and Physics Soil Dept., Desert Research Center, Mattariya, Cairo, Egypt
}

*Corresponding author: h.a.elia@hotmail.com

Received 29 August, 2019

Accepted 9 October, 2019

\section{ABSTRACT}

A field experiment was conducted on sandy soil at Ismailia Governorate. The aim of the present study is to improve the productivity of salts affected sandy soil by treat it with different rates of bentonite, chicken manure and their combination. Soil application rates were bentonite (1, 2.5 and $5 \%$ ), chicken manure (5, 10 and 15 ton/fed) and their combination $(2.5 \%$ bentonite with each of 5,10 and 15 ton /fed chicken manure) were mixed in the upper soil layer $(0-15 \mathrm{~cm}$ soil depth) and their effects on some soil physical properties and crop productivity of fennel plant (Foeniculum Vulgare Mill.) were investigated during the winter season of 2018. Irrigation water used from a well, which has EC, $5.47 \mathrm{dS} . \mathrm{m}^{-1}$ and Sodium adsorption ratio (SAR) 13, under drip irrigation system.

The results revealed that, all studied treatments were significantly decreased of soil bulk density compare to control. The applications of bentonite $1,2.5$ and $5 \%$ lead to, reduction of the value of soil bulk density by $4.17,5.95$ and $10.71 \%$. In addition, the applications of chicken manure 5, 10 and 15 ton/fed, lead to reduction of the value of soil bulk density by $8.93,11.31$ and $14.88 \%$. Also, application of $2.5 \%$ bentonite combined with each of 5,10 and 15 ton/fed chicken manure, lead to reduction of the value of soil bulk density by $11.31,15.48$ and $17.86 \%$ as compared with control, respectively. In reversal the trend in the case of soil porosity values, where soil porosity values were increased with increasing the application rates of bentonite. While, the highest values of soil porosity were with the application rates of combination of 2.5 bentonite + each of 5,10 and 15 ton/fed chicken manure. Data indicated also that there are an increase in the percentages of retained moisture in the soil at all treatments under study. Bentonite and chicken manure individually or combined being higher with increasing the applied rate of bentonite and/or chicken manure. Also the application rates of bentonite $1,2.5$ and $5 \%$ lead to, increasing the values of water-holding pores (WHP) with 6.87, 8.05 and $10.55 \%$. In addition, WHP values increased to $9.21,10.43$ and $11.27 \%$ with the application of chicken manure 5, 10 and 15 ton/fed. Also, data refer that WHP increased to 12.03, 12.81 and $14.11 \%$ by application rate of $2.5 \%$ bentonite combined with each of 5, 10 and 15 ton/fed chicken manure, as compared with control, respectively. The values of water infiltration rates $(\mathrm{cm} / \mathrm{h})$, were affected by different soil applications and can be arranged in the following ascending order: $2.5 \%$ bentonite +15 ton/fed chicken manure $<5 \%$ bentonite $<2.5 \%$ bentonite +10 ton/fed chicken manure $<2.5 \%$ bentonite $<15$ ton/fed chicken manure $<2.5 \%$ bentonite +5 ton/fed chicken manure $<10$ ton/fed chicken manure $<5$ ton/fed chicken manure $<1 \%$ bentonite $<$ control. The water use efficiency values, affected by different soil application can be arranged in the following descending order: $2.5 \%$ bentonite +15 ton/fed chicken manure $>2.5 \%$ bentonite +10 ton/fed chicken manure $>2.5 \%$ bentonite +5 ton/fed chicken manure $>15$ ton/fed chicken manure > 10 ton/fed chicken manure $>5$ ton/fed chicken manure $>5 \%$ bentonite $>2.5 \%$ bentonite $>1 \%$ bentonite $>$ control.

Keyword: Soil physical properties; Water-holding pores; Sandy soil; Infiltration rate; Water use efficiency

\section{INTRODUCTION}

Sandy soils widely exist in arid and semi-arid regions such as the east and west desert areas of Egypt. It is often considered as soils with physical properties easy to define: loss structure or no structure, water retention properties are low, rapid 
permeability, highly sensitivity to erosion with many adverse consequences. Sandy soils productivity is mostly limited by several agronomic obstacles. Their very small specific surface area caused its inert chemical and biological conditions. The fertility level of such soils is very poor and is controlled by their colloid content, such as clay and organic matter Gadalla (1962). Soil conditioners improves the hydro-physical characteristic of soil Wallace and Terry (1998), synthetic and natural conditioner that include many kinds of organic materials, gypsum, lime, natural deposits Sallam et al (1995), Wahab et al (2010). The introduction of bentonite is could be used as a source of soil conditioners to ameliorate of the poor sandy soil properties thus increase the soil productivity. The treatment of varied natural conditioners (bentonite) could overcome those problems Al-Omran et al (2004). The addition of bentonite (clay deposits) to the sandy soil decreased downward water flow and hence restricted deep percolation. Abd El-Hady and El-Dardiry (2012) found that shale deposits added for sandy soil improved physico-chemical characteristic and in particular soil moisture content. Also, continues application improve not only physico-biochemical characteristic of sandy soils, also their productivity. Al-Omran et al (2004) found a decrease in evaporation, infiltration rate and depth of wetting front and consequently increase of wetted area with increasing the bentonite rates up to $4 \%$. It is clear to mention to the importance of organic matter of sandy soils is following the water and considered to overcome the poor physical characteristic especially hydro-physical properties and encourage aggregates formation Abd El-Hady (2005). Abd El-Nasser (2005) mentioned that, improve the physical characteristics of sandy soil such as soil porosity, infiltration rate and soil water content at different tension by application organic conditioners. Bentonite as natural deposits in Egypt was frequently used for conditioning sandy soil. Seddik and Ali (2004) found that added bentonite with chicken manure or compost of rice straw to soil enhance physical of soil characteristics such as soil total porosity and moisture retention characteristics. Wahdan et al (2009) studied the effect of compost, bentonite and gypsum on some hydro-physical properties of soil. They found that the solely and combined treatments showed increased significantly effects on the values of total porosity and available water content. The treated mixture of 1:2 the added rates of organic compost + bentonite shale, increasing total porosity. Such effects of compost and benton- ite shale treatment related to the increase of water holding pores in sandy soil, which can be an index of an ameliorate soil structure. Synthetic and natural soil amendments, are significantly enhanced availability of soil water to plants in the upper layers of the soil. Hussain et al (2001) reported that physical characteristics such as soil bulk density, total porosity, water permeability and hydraulic conductivity were significantly improved when 10 ton.ha ${ }^{-1}$ of farmyard manures was applied in combination with chemical amendments. Tayel et al (2001) added that treats sandy soil with some organic materials increases in water retained, decrease bulk density and increases in total porosity. Also, organic matter and compost were good origin of nutrients and could be beneficial to improve the fertility of sandy soils. Recently, the combination of compost with chemical fertilizer further enhanced the biomass and grain yield of rice and wheat Sarwar et al (2007).

The objective of this study was to investigate the effect of different rates of each bentonite, chicken manure and their combination on salts affected sandy soil, its physical properties and the productivity of fennel plant.

\section{MATERIAS AND METHODS}

A field experiment was conducted on sandy soil at Ismailia Governorate on a private farm during the winter season of 2018 under drip irrigation system. Fennel plant (Foeniculum Vulgare Mill.) was sowing in winter season 2018. Soil application rates were bentonite $(1,2.5$ and $5 \%)$, chicken manure $(5,10$ and 15 ton/fed) and their combination (2.5\% bentonite (Ben.) and each of 5, 10 and 15 ton/fed chicken manure (CM)) were mixed in $15 \mathrm{~cm}$ soil depth. A randomized complete design with 3 replicates was used. Statistical analysis of variance of all studied treatments was ANOVA and the least significant difference (L.S.D) at $0.05 \%$ level. Each plot was $8 \mathrm{~m}^{2}$. Data of soil and bentonite analyses were tabulated in Table (1). Source of irrigation water used from a well, which has EC, $5.47 \mathrm{dS} . \mathrm{m}^{-1}$ and Sodium adsorption ratio (SAR) 13. Plots were supplemented with recommended doses of chemical fertilizers as follows: $300 \mathrm{~kg} / \mathrm{fed}$ calcium super phosphate during soil preparation, while $300 \mathrm{~kg} / \mathrm{fed}$ ammonium sulphate and $100 \mathrm{~kg} / \mathrm{fed}$ potassium sulphate were added during growth season. After harvest of fennel, soil samples were taken from each plot at $0-15 \mathrm{~cm}$ depth in order to determine soil physical properties according to Klute (1986). 
Parameters measured for assessment of the treatment effects were as follows:

Infiltration rate (IR) were measured at the end of experiment and calculated by Philip equation:

$$
\begin{gathered}
D=S . t^{0.5}+A t \\
I=0.5^{\star} S . t^{0.5}+A
\end{gathered}
$$

Where: $D=$ cumulative infiltration, $I=$ basic infiltration rate, $\quad t=$ time, $\quad A$ and $S=$ constants Grain yield; measured at harvest of the crop.

Water use efficiency (WUE): was calculated according to Howell et al (1990) using the following equation: WUE (kg grains. $\mathrm{m}^{-3}$ water) = Grain yield $\left(\mathrm{kg} \mathrm{fed}^{-1}\right) /$ seasonal amount of irrigation water applied $\left(\mathrm{m}^{3} \cdot \mathrm{fed}^{-1}\right)$.

\begin{tabular}{|c|c|c|c|c|c|c|c|c|c|}
\hline Sample & $\begin{array}{l}\text { Course } \\
\text { sand\% }\end{array}$ & $\begin{array}{c}\text { Fine } \\
\text { sand\% }\end{array}$ & Silt\% & Clay\% & Texture & $\begin{array}{c}\text { Bulk } \\
\text { density } \\
\left(\text { Mg. }^{-3}\right)\end{array}$ & pH & $\begin{array}{c}\text { EC }\left(d S . m^{-1}\right) \\
\text { soil extract } \\
(1: 2.5)\end{array}$ & ESP \\
\hline Soil & 18.62 & 76.78 & 3.09 & 1.51 & Sandy & 1.68 & 7.82 & 2.49 & 15.20 \\
\hline Bentonite & 1.32 & 3.15 & 10.61 & 84.92 & Clay & 1.19 & 7.95 & 3.52 & 6.75 \\
\hline
\end{tabular}

Table 1. Some physical and chemical properties of soil and bentonite samples

\section{RESULTS AND DISCUSSION}

\section{Soil bulk density (BD)}

Results in Table (2) reveal that all treatments application seemed to be effective high relatively on soil bulk density. The application of bentonite 1, 2.5 and $5 \%$ lead to, soil $\mathrm{BD}\left(\mathrm{Mg}^{-3}\right)$ values decreased by $1.61,1.58$ and $1.50 \mathrm{Mg} \cdot \mathrm{m}^{-3}$, with reduction of $4.17,5.95$ and $10.71 \%$. In addition, BD val-

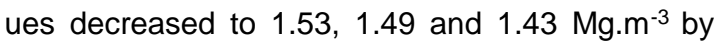
the application of chicken manure 5,10 and 15 ton/fed, with reduction of $8.93,11.31$ and $14.88 \%$.

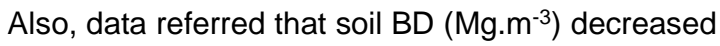
to $1.49,1.42$ and $1.38 \mathrm{Mg} \cdot \mathrm{m}^{-3}$ by application of $2.5 \%$ bentonite (Ben.) combined with each of 5,10 and 15 ton/fed chicken manure (CM), with reduction of $11.31,15.48$ and $17.86 \%$ as compared with control, respectively. These results can be attributed to the redistribution of soil particles, the increase in bulk soil volume and the binding action of bentonite and chicken manure which assess to improve soil structure, mainly in aggregate formation. These findings are very close to that obtained by Omran et al (2002). Table (6) data reveal that addition of bentonite and/or chicken manure to sandy soil significantly decreased soil bulk density $\left(\mathrm{Mg}^{-3} \mathrm{~m}^{-3}\right.$. This result is in agreement with Arvidson (1998) who observed field soils with different texture and organic matter content and found that increasing clay and organic matter content of the soil decreased bulk density did not increase sand content and bulk density. Barzergar et al (2002) also reported that addition of different organic matter types improved soil hydro-physical properties.

\section{Soil porosity (Por.)}

Data in Table (2) showed that the soil porosity (Por.) values increased with different the application and increasing rates of bentonite, chicken manure and their combination. The increasing rates of soil porosity values were $7.24,10.33$ and $18.58 \%$ for application 1, 2.5 and $5 \%$ bentonite. Also the increasing rates of soil porosity values were 15.46, 19.59 and $25.79 \%$ for application 5, 10 and 15 ton/fed chicken manure. While the increasing rates of soil porosity values were 19.59, 26.83 and $30.93 \%$ for application of $2.5 \%$ bentonite combined with each of 5,10 and 15 ton/fed chicken manure as compared with control, respectively. Data also show that the porosity were improved by application different rates of soil amendments. The application of $1,2.5$ and $5 \%$ bentonite, 5,10 and 15 ton/fed chicken manure and combination of $2.5 \%$ bentonite with each of 5,10 and 15 ton/fed chicken manure had high significantly increased of soil porosity Table (6). 
Table 2. Effect of different treatments on some soil physical properties

\begin{tabular}{|c|c|c|c|c|c|c|}
\hline Treatment & Rate & $\begin{array}{c}\text { Bulk } \\
\text { density } \\
\text { Mg.m }{ }^{-3}\end{array}$ & $\begin{array}{c}\text { Porosity } \\
\%\end{array}$ & $\begin{array}{c}\text { Field } \\
\text { capacity } \\
\% \\
\end{array}$ & $\begin{array}{c}\text { Wilting } \\
\text { point } \\
\% \\
\end{array}$ & $\begin{array}{c}\text { Available } \\
\text { water } \\
\% \\
\end{array}$ \\
\hline \multirow{3}{*}{ Bentonite } & $1 \%$ & 1.61 & 39.25 & 8.04 & 1.93 & 6.12 \\
\hline & $2.5 \%$ & 1.58 & 40.38 & 10.47 & 2.29 & 8.18 \\
\hline & $5 \%$ & 1.5 & 43.40 & 12.31 & 2.50 & 9.81 \\
\hline \multirow{3}{*}{$\begin{array}{l}\text { Chicken } \\
\text { Manure }\end{array}$} & 5 ton/fed & 1.53 & 42.26 & 9.12 & 1.65 & 7.47 \\
\hline & 10 ton/fed & 1.49 & 43.77 & 11.55 & 2.01 & 9.54 \\
\hline & 15 ton/fed & 1.43 & 46.04 & 13.39 & 2.22 & 11.17 \\
\hline \multirow{3}{*}{ Combination } & $2.5 \%$ Ben. $+5 \mathrm{CM}$ & 1.49 & 43.77 & 11.07 & 2.31 & 8.76 \\
\hline & $2.5 \%$ Ben.+ 10CM & 1.42 & 46.42 & 14.20 & 2.77 & 11.43 \\
\hline & $2.5 \%$ Ben. $+15 \mathrm{CM}$ & 1.38 & 47.92 & 16.57 & 3.04 & 13.53 \\
\hline \multicolumn{2}{|c|}{ Control } & 1.68 & 36.60 & 6.65 & 1.50 & 5.49 \\
\hline
\end{tabular}

\section{Soil moisture constants}

Retained moisture in sandy soil at field capacity (0.1 bar) and wilting point ( 15 bar) as influenced by different rates of bentonite, chicken manure and their combination were shown in Table (2). Data indicate that adding any of bentonite or chicken manure at any rate increases the retained moisture in sandy soil at any suction. Also increasing in the percentages of retained moisture at all suctions, this increase of retained moisture constants was higher with increasing the applied rate of bentonite or/and chicken manure. Values of retained moisture at field capacity (FC), showed different increasing rates of $20.90,57.44$ and $85.11 \%$ by application of $1,2.5$ and $5 \%$ bentonite. In addition, the increasing rates of retained moisture values at (FC) were $37.14,73.68$ and $101.35 \%$ for application 5,10 and 15 ton/fed chicken manure. While the increasing rates of retained moisture values were $66.47,113.53$ and $149.17 \%$ for application of $2.5 \%$ bentonite combined with each of 5,10 and 15 ton/fed chicken manure as compared with control, respectively. Considering available water, which the difference between moisture at 0.1 bar and that at 15 bar, results show a tendency for increase as influenced by different rates of bentonite, chicken manure and their combination. Data in Table (2) and Fig. (1) showed that an increasing rates of the available water values were 11.48 , 49.00 and $78.69 \%$ by application of $1,2.5$ and $5 \%$ bentonite. Also the increasing rates of available water values were $36.07,73.77$ and $103.46 \%$ for application 5, 10 and 15 ton/fed chicken manure. While the increasing rates of available water values were $59.56,108.20$ and $146.45 \%$ for application of $2.5 \%$ bentonite combined with each of 5,10 and 15 ton/fed chicken manure as compared with control, respectively. The positive effect of bentonite, chicken manure and their combination application in increasing available water reflects the high capacity of these amendments in retaining more moisture in the soil through creating more medium size pores in the soil in particular as well as increasing soil porosity in general. Moreover, the chicken manure was ability to retaining more moisture in the soil higher than bentonite. These results are in agreement with Abd El-Hady and ElDardiry (2012) who mentioned that both soil fine particles such as silt, clay and organic matter content had a potential effect to improve soil ability to retain water and increased soil available water under sandy soils. It is widely used to improve poor soils particular sandy ones.

Also, results in Table (6) showed that water content at field capacity and available water had increased significantly with increasing the rate of bentonite and chicken manure. 


\section{Sandy Soil Productivity}

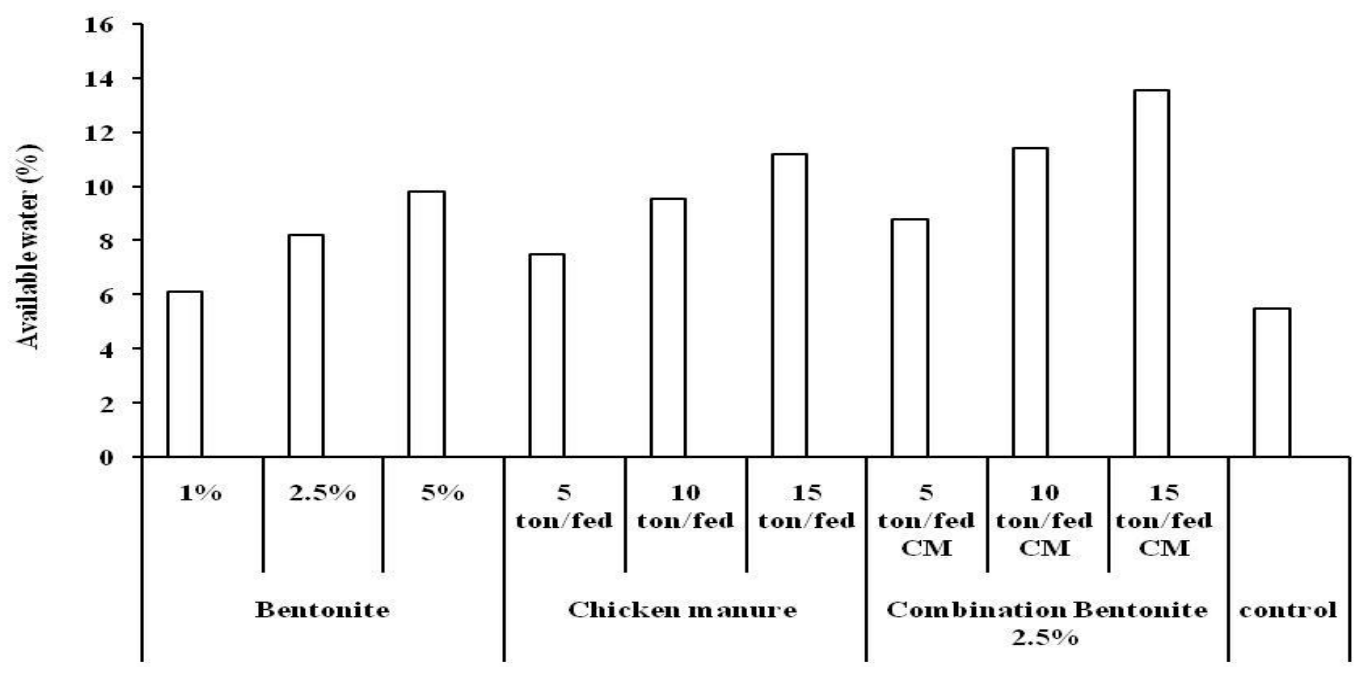

Fig. 1. Available water as affected by different treatments

\section{Pore size distribution}

There was an effect on the distribution of the different fractions of pores. The most positively affected categories of pores were the quickly drainable pores (QDP) and the water-holding pores (WHP). These two categories also represent major portions of soil porosity, and they are of a very important significance in soil fertility and plant growth. Data were shown in Table (3) the QDP values obtained in the current study, the application of bentonite 1, 2.5 and $5 \%$ lead to, QDP values decreased by 29.73, 26.21 and 24.33. In addition, QDP values decreased to $28.61,25.80$ and 22.82 by the application of chicken manure 5,10 and 15 ton/fed. Also, data referred that QDP decreased to $24.18,22.83$ and 21.13 by application of $2.5 \%$ bentonite combined with each of 5,10 and 15 ton/fed chicken manure, as compared with control, respectively.

While the application of bentonite 1,2.5 and $5 \%$ lead to, the water-holding pores (WHP) values increased by $6.87,8.05$ and 10.55 . In addition, WHP values increased to $9.21,10.43$ and 11.27 by the application of chicken manure 5, 10 and 15 ton/fed. Also, data referred that WHP increased to $12.03,12.81$ and 14.11 by application of $2.5 \%$ bentonite combined with each of 5, 10 and 15 ton/fed chicken manure, as compared with control, respectively.

Therefore, the positive effect of bentonite or/and chicken manure addition from the view point of porosity is in terms of redistribution of pore size fractions so as to increase the water-useful fractions in particular, which represent a significant portion of the pores and hold easily available water for plants. Such changes in the pattern of pore size distribution would be reflected in increased water holding capacity, and would most certainly contribute in greater plant growth and ultimately higher grain yields as shown by the relevant data of these parameters. The most effective was that of application of $2.5 \%$ bentonite combined with 15 ton/fed chicken manure.

These results may be attributed to the redistribution of solid particles after the existing of label bentonite and chicken manure. In this case, soil aggregates can be established, hence the water holding pores increased and consequently available moisture in the treated soils. Loveday (1974). Increased proportions of water useful pores as a result of adding organic soil conditioners was observed Abd El-Salam et al (2006) and Ali (2011) who applied organic manure up to $27 \mathrm{Mg} \mathrm{f}^{-1}$. Evanylo et al (2008) who reported increased porosity as well as decreased bulk density upon adding rates of organic composts equivalent to 7.0 to 14.0 Mg. $\mathrm{f}^{-1}$ under different organic farming systems. Also, adding bentonite or/and chicken manure leads to significant change in pore size distribution due to high organic matter in chicken manure and fine particles in bentonite which leads to an increase in fine capillary pores on the expense of quickly drainable pore and consequently, an increase of the retained moisture in sandy soil, Table (6). 
Table 3. Effect of different treatments on pore size distribution

\begin{tabular}{|c|c|c|c|c|c|}
\hline Treatment & Rate & $\begin{array}{c}\text { QDP } \\
>28.8 \mu\end{array}$ & $\begin{array}{c}\text { SDP } \\
28.8-8.6 \mu\end{array}$ & $\begin{array}{c}\text { WHP } \\
8.6-0.19 \mu\end{array}$ & $\begin{array}{c}\text { FCP } \\
<0.19 \mu\end{array}$ \\
\hline \multirow{3}{*}{ Bentonite } & $1 \%$ & 29.73 & 3.97 & 6.87 & 2.17 \\
\hline & $2.5 \%$ & 26.21 & 4.11 & 8.05 & 2.53 \\
\hline & $5 \%$ & 24.33 & 6.07 & 10.55 & 2.82 \\
\hline \multirow{3}{*}{$\begin{array}{l}\text { Chicken } \\
\text { Manure }\end{array}$} & 5 ton/fed & 28.61 & 6.72 & 9.21 & 1.97 \\
\hline & 10 ton/fed & 25.80 & 8.13 & 10.43 & 2.06 \\
\hline & 15 ton/fed & 22.82 & 10.18 & 11.27 & 1.92 \\
\hline \multirow{3}{*}{ Combination } & $2.5 \%$ Ben. $+5 \mathrm{CM}$ & 24.18 & 9.48 & 12.03 & 2.59 \\
\hline & $2.5 \%$ Ben.+ $10 \mathrm{CM}$ & 22.83 & 11.32 & 12.81 & 2.81 \\
\hline & $2.5 \%$ Ben.+ $15 \mathrm{CM}$ & 21.13 & 13.78 & 14.11 & 2.97 \\
\hline \multicolumn{2}{|c|}{ Control } & 31.69 & 2.91 & 3.16 & 1.93 \\
\hline
\end{tabular}

Infiltration rate (IR)

$$
I=0.5 * S . t^{0.5}+A
$$

Regarding to the obtained equations. If we expressed on $A$ by intersect of the $Y$ axis at time 1 min. and $S$ it is the slope. These constants ( $A$ and S) are useful indicators that water intake in soil where A expresses on the volume of water that intake in soil vertically through unite area from soil surface after one minute from starting the infiltration determination whereas, $S$ expresses the changes in water intake with time. Table (4) show these constants as affected by different application rates of bentonite, chicken manure and their combination.

Soil Infiltration rate $(\mathrm{IR})(\mathrm{cm} / \mathrm{h})$ is the volume flux of water flowing into the profile per unit of soil surface area. Table (4) and Figs. (2-4) show that the application of bentonite $1,2.5$ and $5 \%$ lead to, IR values decreased by 29.28, 19.04 and 17.14 $\mathrm{cm} / \mathrm{h}$, with reduction of $25.89,51.81$ and $56.62 \%$. In addition, IR values decreased to $29.24,25.50$ and $22.34 \mathrm{~cm} / \mathrm{h}$ with the application of chicken manure 5,10 and 15 ton/fed, with reduction of $26.00,35.46$ and $43.46 \%$. Also, data referred that IR decreased to $23.51,18.07$ and $15.71 \mathrm{~cm} / \mathrm{h}$ by application of $2.5 \%$ bentonite combined with each of 5,10 and 15 ton/fed chicken manure, with reduction of $40.50,54.27$ and $60.24 \%$ as compared with control, respectively. The values of infiltration rate, affected by different soil application can be arranged in the following ascending order: $2.5 \%$ bentonite +15 ton/fed chicken manure $<5 \%$ bentonite $<2.5 \%$ bentonite +10 ton/fed chicken manure $<2.5 \%$ bentonite $<15$ ton/fed chicken manure $<2.5 \%$ bentonite +5 ton/fed chicken manure $<10$ ton/fed chicken manure $<5$ ton/fed chicken manure $<1 \%$ bentonite $<$ control. Data in Table (6) reveal that the effect of application bentonite, chicken manure and their combination in different rates were decreased significantly compared to control, this resulted data agreement with Saied et al (2017).

It is also evident that the rate of water entry into the soil treated with different rates of bentonite, chicken manure and their combination, is relatively lower than that in the control. This behavior may be ascribed to the relatively higher content rates of bentonite, chicken manure and their combination, which may result in partial blocking of soil pores with modification of the pore size distribution, which result in increasing the micro pores and thus decrease in the basic infiltration rates of treatments compared to control. 
Table 4. Effect of different treatments on soil infiltration rates

\begin{tabular}{|c|c|c|c|c|c|c|c|}
\hline \multirow{2}{*}{ Treatment } & \multirow{2}{*}{ Rate } & \multirow{2}{*}{ Equation } & \multicolumn{4}{|c|}{ Infiltration parameters } & \multirow{2}{*}{$\mathbf{R}^{2}$} \\
\hline & & & S & $\mathbf{A}$ & I (mm/h) & $D(\mathrm{~mm})$ & \\
\hline \multirow{6}{*}{ Bentonite } & \multirow{2}{*}{$1 \%$} & $\mathrm{D}=\mathrm{S} . \mathrm{t}^{0.5}+\mathrm{At}$ & \multirow{2}{*}{4.9912} & \multirow{2}{*}{0.3115} & \multirow{2}{*}{29.28} & \multirow{2}{*}{132.89} & \multirow{2}{*}{0.995} \\
\hline & & $I=0.5^{*}$ S.t. $\mathrm{t}^{-0.5}+\mathrm{A}$ & & & & & \\
\hline & \multirow{2}{*}{$2.5 \%$} & $\mathrm{D}=\mathrm{S} \cdot \mathrm{t}^{0.5}+\mathrm{At}$ & \multirow{2}{*}{3.2994} & \multirow{2}{*}{0.2010} & \multirow{2}{*}{19.04} & \multirow[b]{2}{*}{86.80} & \multirow{2}{*}{0.998} \\
\hline & & $I=0.5^{*} S . t^{-0.5}+\mathrm{A}$ & & & & & \\
\hline & \multirow[b]{2}{*}{$5 \%$} & $\mathrm{D}=\mathrm{S} \cdot \mathrm{t}^{0.5}+\mathrm{At}$ & \multirow{2}{*}{5.7059} & \multirow{2}{*}{0.0840} & \multirow{2}{*}{17.14} & \multirow{2}{*}{97.49} & \multirow{2}{*}{0.998} \\
\hline & & $I=0.5^{*} S . t^{-0.5}+A$ & & & & & \\
\hline \multirow{6}{*}{$\begin{array}{l}\text { Chicken } \\
\text { Manure }\end{array}$} & \multirow{2}{*}{5 ton/fed } & $D=S \cdot t^{0.5}+A t$ & \multirow{2}{*}{5.6875} & \multirow{2}{*}{0.2863} & \multirow{2}{*}{29.24} & \multirow{2}{*}{137.69} & \multirow{2}{*}{0.993} \\
\hline & & $I=0.5^{*}$ S.t. $\mathrm{t}^{-0.5}+\mathrm{A}$ & & & & & \\
\hline & \multirow{2}{*}{10 ton/fed } & $\mathrm{D}=\mathrm{S} . \mathrm{t}^{0.5}+\mathrm{At}$ & \multirow{2}{*}{4.8218} & \multirow{2}{*}{0.2545} & & & \\
\hline & & $I=0.5^{*}$ S.t. $\mathrm{t}^{-0.5}+\mathrm{A}$ & & & 25.50 & 119.09 & 0.984 \\
\hline & $15 \mathrm{ton} / \mathrm{f}$ d & $\mathrm{D}=\mathrm{S} . \mathrm{t}^{0.5}+\mathrm{At}$ & 40186 & 02303 & 2234 & 10289 & 0998 \\
\hline & 15 ton/ted & $I=0.5^{*} S . t^{-0.5}+A$ & 4.0100 & 0.2300 & $2<.34$ & 102.89 & 0.998 \\
\hline & $25 \%$ Ren 15 CM & $\mathrm{D}=\mathrm{S} . \mathrm{t}^{0.5}+\mathrm{At}$ & & & & & \\
\hline & $2.5 \%$ benl.+5 CIVI & $I=0.5^{*}$ S.t. $t^{-0.5}+\mathrm{A}$ & 6.1685 & $0.1 / 38$ & 23.51 & 121.99 & 0.991 \\
\hline Combination & $25 \% \operatorname{Ren} 110 \mathrm{CM}$ & $\mathrm{D}=\mathrm{S} . \mathrm{t}^{0.5}+\mathrm{At}$ & 43373 & 01479 & 1807 & 9092 & 0.997 \\
\hline comomation & $2.5 \%$ benl.t 10 CIVI & $I=0.5^{\star} S \cdot t^{-0.5}+A$ & 4.3313 & $0.14 / 9$ & 10.07 & 90.92 & 0.991 \\
\hline & & $\mathrm{D}=\mathrm{S} \cdot \mathrm{t}^{0.5}+\mathrm{At}$ & 11 & 0 & 11 & 7691 & 993 \\
\hline & $2.5 \%$ Ben.+ 15 CIVI & $I=0.5^{*} S . t^{-0.5}+A$ & ग & U. & 15.11 & 70.91 & 0.993 \\
\hline & & $D=S . t^{0.5}+A t$ & & & 1 & 174.44 & \\
\hline & ntrol & $I=0.5^{\star} S \cdot t^{-0.5}+A$ & & & & 174.44 & .991 \\
\hline
\end{tabular}

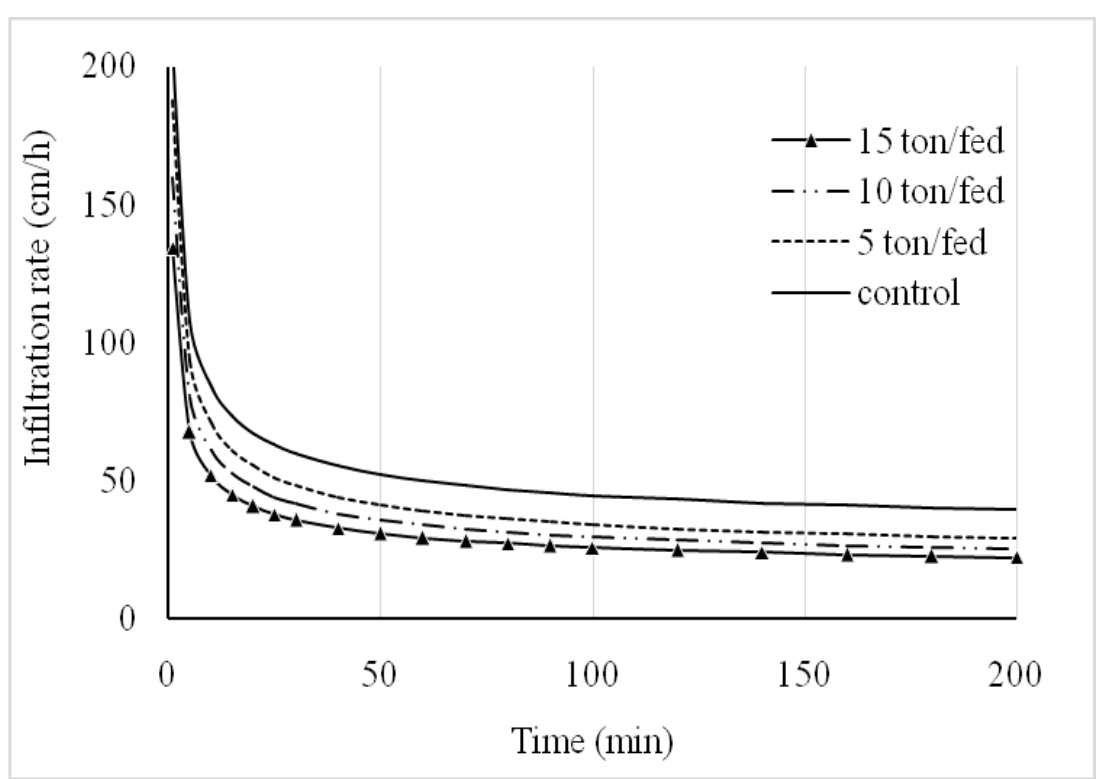

Fig. 2. Infiltration rates $(\mathrm{cm} / \mathrm{h})$ as affected by different rates of bentonite treatments 


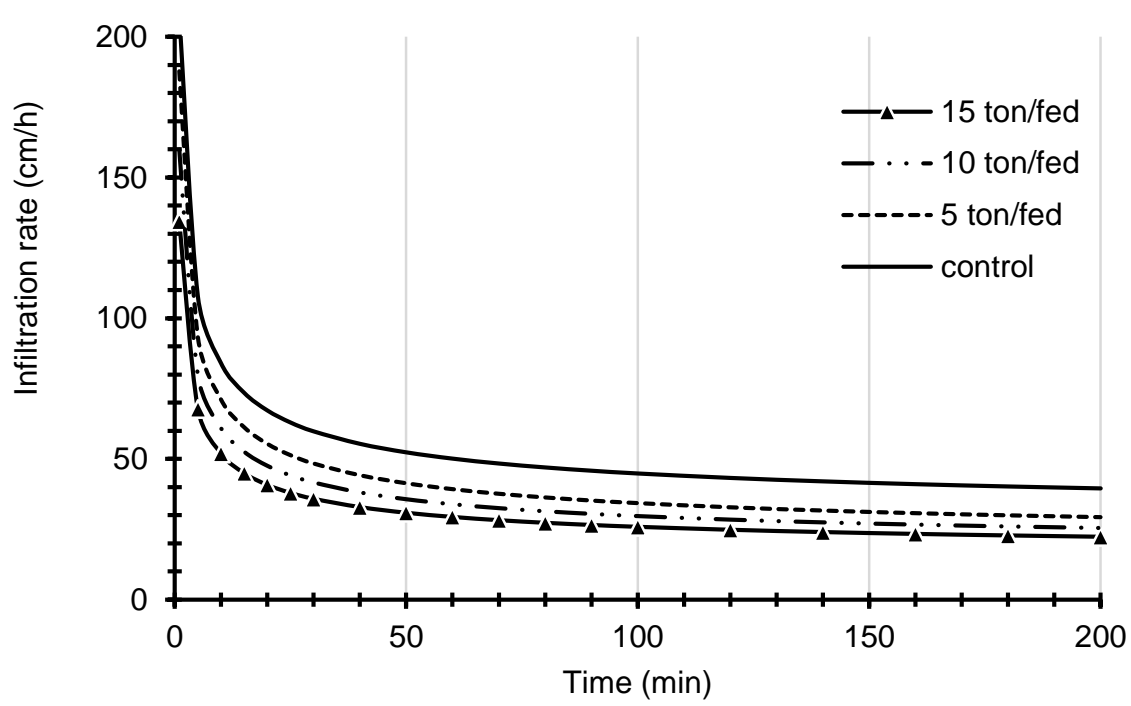

Fig. 3. Infiltration rates $(\mathrm{cm} / \mathrm{h})$ as affected by different rates of chicken manure treatments

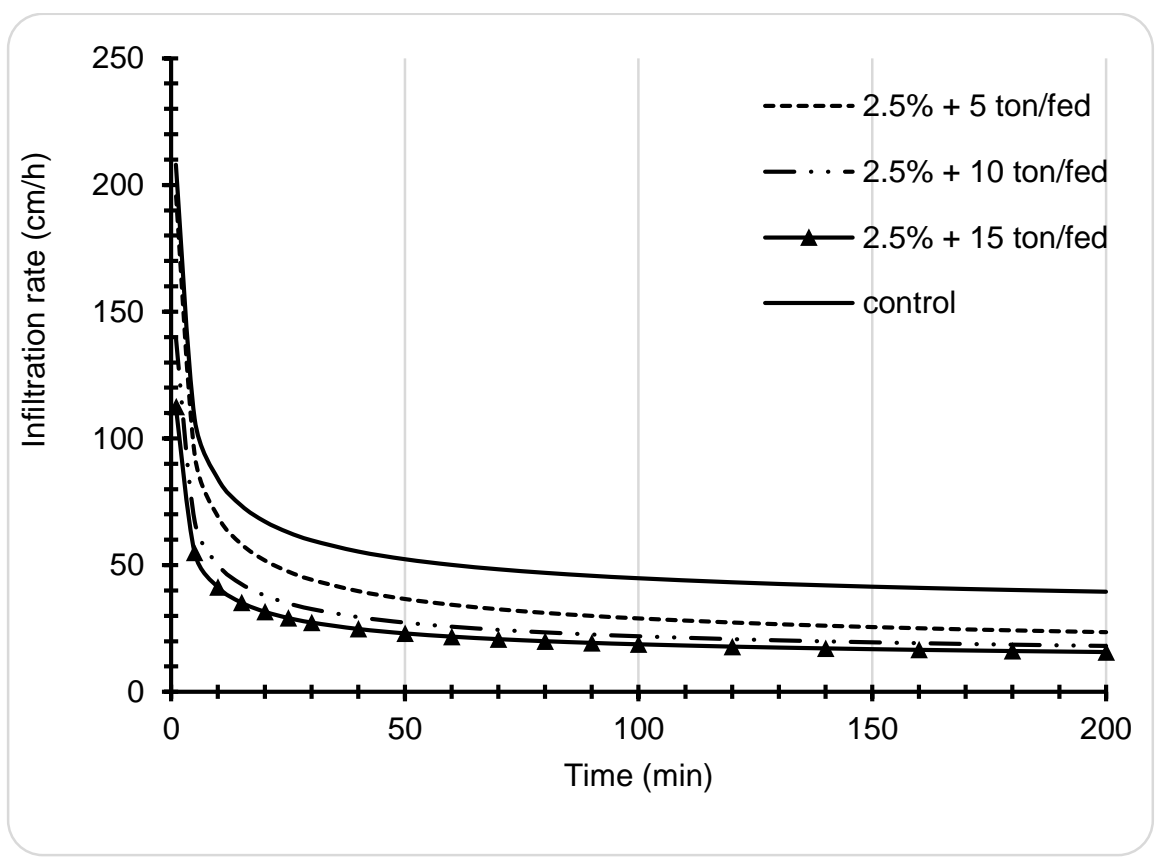

Fig. 4. Infiltration rates $(\mathrm{cm} / \mathrm{h})$ as affected by different rates of combination bentonite + chicken manure treatments 
Sandy Soil Productivity

\section{Water Use Efficiency (WUE)}

Values of the water use efficiency, which reflect the relation between the production and the total seasonal water used are presented in Table (5) and Fig. (5). Data show that treating the sandy soil with tested conditioners led to an increase in water use efficiency by growing fennel plants in $\mathrm{kg}$ per each cubic meter of irrigation water used. Regarding to the water use efficiency (WUE) of fennel grain yield as affected by application of bentonite, chicken manure and their combination under different rates, data pointed out that almost application of combination bentonite + chicken manure, had a superior effect on WUE of fennel grain yield than each of bentonite or chicken manure alone. Also, data indicated that maximize WUE of grains fennel were combination $2.5 \%$ bentonite +15 ton/fed chicken manure followed by $2.5 \%$ bentonite +10 ton/fed chicken manure, greater than $2.5 \%$ bentonite +5 ton/fed chicken manure. The application of bentonite 1, 2.5 and $5 \%$ lead to, WUE values increased by $0.63,0.65$ and $0.67 \mathrm{~kg} \cdot \mathrm{m}^{-3}$, with increasing rate to $10.11,13.62$ and $17.29 \%$. In addition, WUE values increased to $0.71,0.75$ and $0.77 \mathrm{~kg} \cdot \mathrm{m}^{-3}$ by the application of chicken manure 5 , 10 and 15 ton/fed, with increasing rate to 24.31 , 31.50 and $35.00 \%$. Also, data referred that WUE increased to $0.83,0.87$ and $0.93 \mathrm{~kg} \cdot \mathrm{m}^{-3}$ by application of $2.5 \%$ bentonite combined with each of 5,10 and 15 ton/fed chicken manure, with increasing rate to $45.70,52.72$ and $63.41 \%$ as compared with control, respectively. From these results, it was concluded that under restricted water used that application bentonite, chicken manure and their combination at different rates to soil will provide fennel plants by their needs of irrigation water without any stress, this resulted data agreement with Hussein et al (2013).

The WUE as affected by different soil application can be arranged in the following descending order: $2.5 \%$ bentonite +15 ton/fed chicken manure $>2.5 \%$ bentonite +10 ton/fed chicken manure > $2.5 \%$ bentonite +5 ton/fed chicken manure $>15$ ton/fed chicken manure $>10$ ton/fed chicken manure $>5$ ton/fed chicken manure $>5 \%$ bentonite $>$ $2.5 \%$ bentonite $>1 \%$ bentonite $>$ control.

Table 5. Effect of different treatments on fennel grains yield and WUE

\begin{tabular}{|c|c|c|c|c|c|c|}
\hline Treatment & Rate & $\begin{array}{c}\text { No. } \\
\text { branch/ } \\
\text { plant }\end{array}$ & $\begin{array}{c}\text { No. of } \\
\text { Umbels/ } \\
\text { plant }\end{array}$ & $\begin{array}{c}\text { Weight } \\
\text { grains/plant } \\
\text { (gm) }\end{array}$ & $\begin{array}{c}\text { Grains } \\
\text { yield } \\
\left(\text { kg.fed }^{-1}\right)\end{array}$ & $\begin{array}{l}\text { WUE } \\
\left(\mathbf{k g} \cdot \mathrm{m}^{-3}\right)\end{array}$ \\
\hline \multirow{3}{*}{ Bentonite } & $1 \%$ & 6 & 28 & 42.6 & 659 & 0.63 \\
\hline & $2.5 \%$ & 8 & 35 & 45.8 & 680 & 0.65 \\
\hline & $5 \%$ & 9 & 38 & 49.1 & 702 & 0.67 \\
\hline \multirow{3}{*}{$\begin{array}{l}\text { Chicken } \\
\text { Manure }\end{array}$} & 5 ton/fed & 8 & 32 & 51.6 & 744 & 0.71 \\
\hline & 10 ton/fed & 8 & 36 & 54.8 & 787 & 0.75 \\
\hline & 15 ton/fed & 9 & 40 & 59.2 & 808 & 0.77 \\
\hline \multirow{3}{*}{ Combination } & $2.5 \%$ Ben. $+5 \mathrm{CM}$ & 9 & 41 & 62.6 & 872 & 0.83 \\
\hline & $2.5 \%$ Ben.+ $10 \mathrm{CM}$ & 10 & 43 & 65.3 & 914 & 0.87 \\
\hline & $2.5 \%$ Ben.+ $15 \mathrm{CM}$ & 11 & 46 & 69.9 & 978 & 0.93 \\
\hline \multicolumn{2}{|c|}{ Control } & 5 & 20 & 40.5 & 595 & 0.57 \\
\hline
\end{tabular}




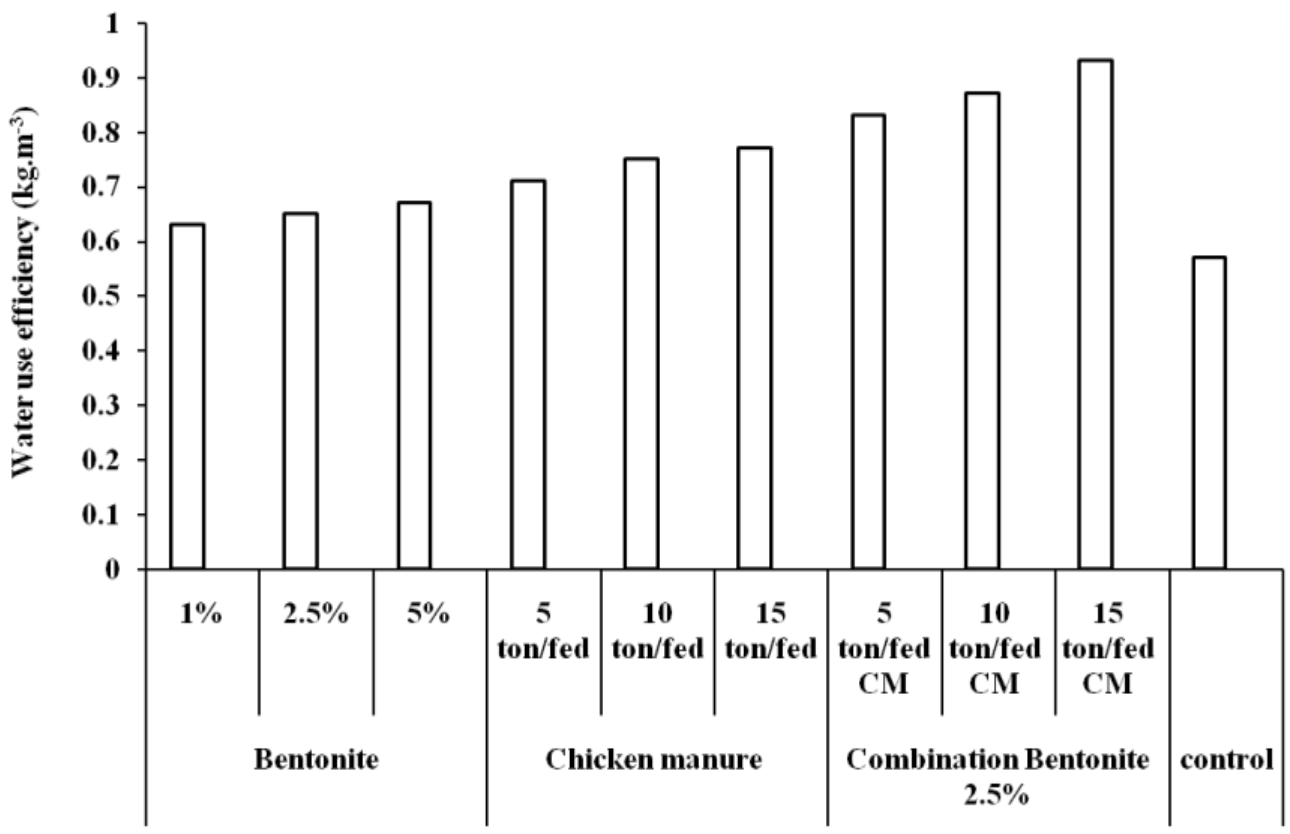

Fig. 5. Water use efficiency as affected by different treatments.

Yield

Small amounts of bentonite increase growth rates and yields of many plants in sandy soil. Table (5) illustrated the effect of different rates of bentonite, chicken manure and their combination. The increasing rates of fennel grains yield values were 10.76, 14.29 and $17.98 \%$ for application 1, 2.5 and $5 \%$ bentonite. Also the increasing rates of fennel grains yield values were 25.04, 32.27 and $35.80 \%$ for application 5, 10 and 15 ton/fed chicken manure. While the increasing rates of fennel grains yield values were $46.55,53.61$ and $64.37 \%$ for application of $2.5 \%$ bentonite combined with each of 5,10 and 15 ton/fed chicken manure as compared with control, respectively. Data show that the highest of fennel grains yield was under treatment $2.5 \%$ bentonite +15 ton/fed chicken manure. The application of $1,2.5$ and $5 \%$ bentonite, 5,10 and 15 ton/fed chicken manure and combination of $2.5 \%$ bentonite with each of 5,10 and 15 ton/fed chicken manure had high significantly increased the fennel grains yield Table (6). ElKholy et al (2000) and Hassan \& Abdel Wahab (2013) supported the obtained data, and attributed the increase in yield to the soil ability to storage water for plant till needed. 
Table 6. Statistical analysis ANOVA of soil treatments and their rates on some soil physical and yield

\begin{tabular}{|c|c|c|c|c|c|c|c|c|c|c|c|c|}
\hline \multicolumn{2}{|c|}{ Soil property } & \multirow{2}{*}{$\begin{array}{c}\text { BD } \\
* * \\
0.06 \\
\end{array}$} & \multirow{2}{*}{$\begin{array}{c}\text { Por. } \\
* * \\
1.29 \\
\end{array}$} & \multirow{2}{*}{$\begin{array}{l}\text { F.C. } \\
* * * \\
0.23 \\
\end{array}$} & \multirow{2}{*}{$\begin{array}{c}\text { A.W } \\
* \star * \\
0.193 \\
\end{array}$} & \multirow{2}{*}{$\begin{array}{c}\text { QDP } \\
\star \star \star \\
1.11 \\
\end{array}$} & \multirow{2}{*}{$\begin{array}{l}\text { SDP } \\
* \star * \\
0.10 \\
\end{array}$} & \multirow{2}{*}{$\begin{array}{c}\text { WHP } \\
* \star * \\
0.11 \\
\end{array}$} & \multirow{2}{*}{$\begin{array}{c}\text { FCP } \\
* * * \\
0.07 \\
\end{array}$} & \multirow{2}{*}{\begin{tabular}{c|} 
IR \\
$* * *$ \\
1.4 \\
\end{tabular}} & \multirow{2}{*}{\begin{tabular}{|c|} 
WUE \\
$* * *$ \\
0.02 \\
\end{tabular}} & \multirow{2}{*}{$\begin{array}{c}\text { Yield } \\
* * * \\
20.9 \\
\end{array}$} \\
\hline Treatment & $\begin{array}{c}\text { Sign. } \\
\text { LSD }_{0.05}\end{array}$ & & & & & & & & & & & \\
\hline Rates & $\begin{array}{c}\text { Sign. } \\
\text { LSD }_{0.05} \\
\end{array}$ & $\begin{array}{c}* \\
0.05 \\
\end{array}$ & $\begin{array}{c}* \\
2.23 \\
\end{array}$ & $\begin{array}{l}* * * \\
0.40 \\
\end{array}$ & $\begin{array}{l}* * * \\
0.33 \\
\end{array}$ & $\begin{array}{c}* \\
1.93 \\
\end{array}$ & $\begin{array}{l}* * * \\
0.18 \\
\end{array}$ & $\begin{array}{l}* \star * \\
0.19 \\
\end{array}$ & $\begin{array}{c}* * \\
0.12 \\
\end{array}$ & $\begin{array}{c}* * \\
2.40 \\
\end{array}$ & $\begin{array}{c}* \\
0.035 \\
\end{array}$ & $\begin{array}{c}* \\
36.20 \\
\end{array}$ \\
\hline \multicolumn{13}{|c|}{ Rank Mean of treatments addition } \\
\hline \multicolumn{2}{|c|}{ Bentonite } & $\mathrm{b}$ & C & c & c & $\mathrm{b}$ & C & c & $b$ & c & c & c \\
\hline \multicolumn{2}{|c|}{ Chicken manure } & $b$ & $b$ & $b$ & $b$ & $b$ & $b$ & $\mathrm{~b}$ & c & $b$ & $b$ & b \\
\hline \multicolumn{2}{|c|}{ Bentonite + Chicken M } & c & $\mathrm{a}$ & $\mathrm{a}$ & $\mathrm{a}$ & c & $\mathrm{a}$ & a & $\mathrm{a}$ & d & $\mathrm{a}$ & a \\
\hline \multicolumn{2}{|c|}{ Control } & $\mathbf{a}$ & d & d & d & $\mathbf{a}$ & d & d & c & $\mathbf{a}$ & d & d \\
\hline \multicolumn{13}{|c|}{ Rank Mean of treatments rates addition } \\
\hline \multicolumn{2}{|c|}{$1 \%$ Bentonite } & b & $d$ & $\mathrm{i}$ & $g$ & $b$ & $\mathrm{~h}$ & $\mathrm{~h}$ & $d$ & $b$ & $g$ & $g$ \\
\hline \multicolumn{2}{|c|}{$2.5 \%$ Bentonite } & $b$ & $\mathrm{~cd}$ & $g$ & e & c & $\mathrm{h}$ & g & c & e & $\mathrm{fg}$ & $\mathrm{fg}$ \\
\hline \multicolumn{2}{|c|}{$5 \%$ Bentonite } & c & bc & $d$ & $f$ & $\mathrm{~cd}$ & $g$ & e & b & ef & $f$ & $f$ \\
\hline \multicolumn{2}{|c|}{5 ton/fed $\mathrm{CM}$} & c & $b$ & $\mathrm{~h}$ & d & $\mathrm{b}$ & $f$ & $f$ & ef & bf & e & e \\
\hline \multicolumn{2}{|c|}{10 ton/fed CM } & $\mathrm{cd}$ & $b$ & e & c & $\mathrm{cd}$ & e & e & de & c & $d$ & $d$ \\
\hline \multicolumn{2}{|c|}{15 ton/fed CM } & $d$ & a & c & $b$ & ef & $c$ & $d$ & $f$ & $d$ & $d$ & $d$ \\
\hline \multicolumn{2}{|c|}{ 2.5 Ben+5 ton/fed CM } & $\mathrm{cd}$ & $\mathrm{b}$ & $f$ & c & de & $d$ & c & c & $\mathrm{cd}$ & c & c \\
\hline \multicolumn{2}{|c|}{ 2.5 Ben+10 ton/fed CM } & $d$ & $\mathrm{a}$ & b & $b$ & ef & b & b & $b$ & ef & $b$ & b \\
\hline \multicolumn{2}{|c|}{$2.5 \mathrm{Ben}+15$ ton/fed CM } & de & $\mathrm{a}$ & $\mathrm{a}$ & $\mathrm{a}$ & $f$ & $\mathrm{a}$ & $\mathrm{a}$ & $\mathrm{a}$ & $f$ & $\mathrm{a}$ & $\mathrm{a}$ \\
\hline \multicolumn{2}{|c|}{ Control } & $\mathbf{a}$ & e & j & h & a & $\mathbf{i}$ & $\mathbf{i}$ & $f$ & $\mathbf{a}$ & $\mathbf{h}$ & h \\
\hline
\end{tabular}

\section{CONCLUSIONS}

From the above mentioned results, it can be concluded that increasing application rates of bentonite, chicken manure and their combination led to improve the soil physical properties under investigation, especially the treatment combination of $2.5 \%$ bentonite with 15 ton/fed chicken manure. In case of different rates bentonite treatment alone it could be recommended as a suitable material in order to supply clay fraction to sandy soil, high rates of bentonite should be avoided. Application combination of bentonite + chicken manure could be used economically for maximizing water use efficiency.

\section{REFERENCES}

Abd El-Hady M. 2005. Relations between some soil properties and soil moisture constants us- ing path analysis. Egypt. J. Appl. Sci., 20(5), 404-411.

Abd El-Hady M. and El-Dardiry E.I. 2012. Sustainable reclamation of newly reclaimed sandy soil through local marine deposits application: IImprovement of hydro-physical characteristics. J. of Applied Sci. Research, 8(4), 2350-2355.

Abd El-Nasser G. 2005. Improving physical and hydro-physical propertiesof sandy soil with organic conditioners. Saudi Agriculture: Opportunitiesand Challenges. Saudi Society of Agric. Sci. $2^{\text {nd }}$ Symposium, pp. 13-15.

Abd El-Salam A.A., Ibrahim M.A.M., Abass H.H. and Kassab M.M. 2006. Interaction relationships of irrigation level and furrow spacing on crop water parameters of sunflower. Annals of Agric. Sci. Moshtohor 44(2), 769-774.

Ali, K.M. 2011. Significance of applied cellulose polymer and organic manure for ameliorating hydrohysic-chemical properties of sandy soil 
and maize yield. Aust. J. of Basic and Appl. Sci., 5, 23-35.

Al-Omran A.M., Falatah A.M., Sheta A.S. and AlHarbi A.R. 2004. Clay deposits for water management of sandy soils. Arid Land Res. Manage., 18, 171-184.

Arvidson J. 1998. Influence of soil texture and organic matter content on bulk density, air content, compression index and crop yield in field and laboratory compression experiments. Soil and Tillage Research 49, 159-170.

Barzegar A.R., Yousefi A. and Daryashenas A. 2002. The effect of addition of different amounts and types of organic materials on soil physical properties and yield of wheat. Plant and Soil 247, 295-301.

El-Kholy H.E.M., Abou El-Defan T.A. and ElGhanam M.M.M. 2000. Influence of some natural soil conditioners on wheat grown on sandy soils. J. Agric. Sci. Mansoura Univ., Mansoura, Egypt, 25, 5953-5971.

Evanylo G., Sherony C., Spargo J., Starner D., Brosius M. and Hearing K. 2008. Soil and water environmental effects of fertilizer, manure, and compost based fertility practices in organic vegetable cropping systems Agric. Ecosystems and Environment 127, 50-58.

Gadalla S.M. 1962. Land reform in relation to social development Egypt. Columbia: Univ. of Missouri Press, 139 p.

Hassan A.Z.A. and Abdel Wahab M.M. 2013. The combined effect of bentonite and natural zeolite on sandy soil properties and productivity of some crops. J. of Agric. Res., 1(3), 22-28.

Howell T.A., Cuence R.H. and Solomon K.H 1990. Crop yield response. In: Management of farm irrigation systems. Hoffman G.J., Howell T.A. and Solomon K.H. (Eds.). ASAE, St. Joseph, MI., USA, 312 p.

Hussain N., Hassan G., Arshadullah M. and Mujeeb F. 2001. Evaluation of amendments for the improvement of physical properties of sodic soil. Intl. J. Agric. Bio., 3, 319-322.

Hussein M.M., Safaa A.M. and Taalab A.S. 2013. Yield and nutrient status of barley plant in response to foliar application of fertilizers under water deficit conditions. J. of Applied Sci. Research, 9(7), 4388-4396.

Klute A. 1986. Methods of soil analysis. Part1. Physical and microbiological methods. $2^{\text {nd }}$ ed. Agronomy. Monogr. 9. ASA and SSSA, Madison, WI. pp. 28-35
Loveday I. 1974. Methods for analysis of irrigated soils. Technical communication No. of the Commonwealth Bureau of Soils, Commonwealth Agricultural Bureaux. 208 p.

Omran A.M., Falatah A.M. and Al-Harbi A.R. 2002. The use of natural deposits as an alternative for polymers on water management in arid calcareous sandy soils of Saudi Arabia. $17^{\text {th }}$ World Congress of Soil Sci., 14-21 August, Thailand. 18, 1-13.

Saied M.M., Elsanat G.M., Talha N.I. and El Barbary S.M. 2017. On farm soil management practices for improving soil properties and productivity of rice and wheat under saltaffected soils at North Delta. Egypt. J. Soil Sci. 57(4), 445-453.

Sallam A.S.H., Elwan A.A. and Rabie F.H. 1995. Shale deposits of El-Farafra depression (Egypt) as soil conditioner for sandy soils. Arid Soil Res. Rehabil., 9, 209-217.

Sarwar G., Hussain N., Schmeisky H., Sarwar S., Hussain G.N. and Muhammad S. 2007. Use of compost an environment friendly technology for enhancing rice-wheat production in Pakistan. Pak. J. Bot., 39, 1553-1558.

Seddik M.A. and Ali K.M. 2004. Effect of some natural soil amendments on some soil physical properties, peanut and carrot yields in a sandy soil. Egypt. J. Agric. Res., 82, 95-105.

Tayel M.Y., Ghazy A., Abdel Aal R.S. and Wanas Sh.A. 2001. Improving sand soils using cellulose derivatives. 2: pore size distribution, soil water retention, soil hydraulic conductivity and soil hydraulic resistivity. Egypt. J. Soil Sci., 41, 210-231.

Wahab M.A., Ageeb G.W. and Labib F. 2010. The agricultural investments of some shale deposits in Egypt. J. of American Sci., 6(9), 7581.

Wahdan A.A.A., Ibrahim A.E.M. and Bakry M.A.A. 2009. Integrated input soil and water managements in maximizing peanut crop under the eastern drought - front desert qutskirt of El Fayoum governorate, Egypt. Res. J. of Agric. and Biol. Sci., 5, 1-15.

Wallace A. and Terry R.E. 1998. Introduction: Soil Conditioners, Soil Quality and Soil Sustainability. In: Handbook of Soil Conditioners, Wallace, A. and R.E. Terry (Eds.). Marcel Dekker, Inc., New York, USA, pp. 45-47. 
مجلة اتحاد الجامعات العربية للعلوم الزراعية، جامعة عين شمس، القاهرة، مصر مجلا(27)، عدد(3)، 2036-2023، 2019 Website: http://ajs.journals.ekb.eg

تأثير بعض الممارسات الزراعية على تحسين انتاجية التربة الرملية المتأثرة بالاملاح

\author{
هدى عبده إيليا" - ضياء سعيد منير بولس

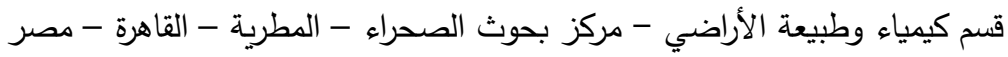

*Corresponding author: h.a.elia@hotmail.com

Received 29 August, 2019

Accepted 9 October, 2019

الظاهريـة بنسبة 11.31, 15.48, 17.86٪ مقارنــة

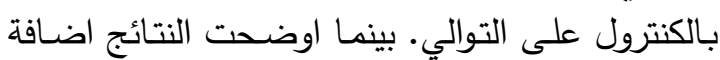
هذه المعاملات بمعدلاتها المختلفة زيادة معنويـة فى قيم

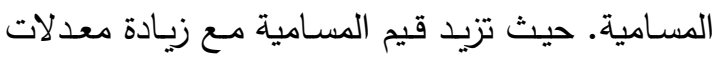

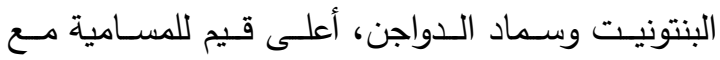

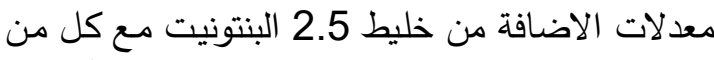

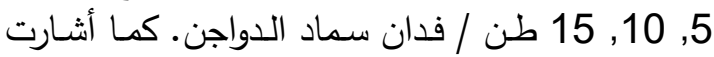

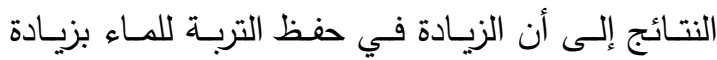

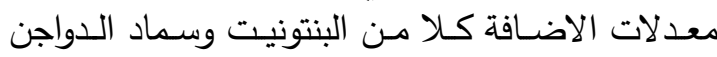

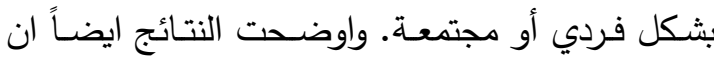

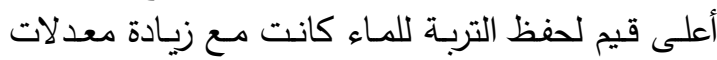

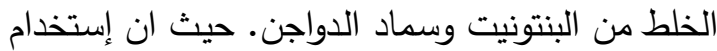

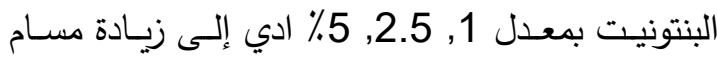

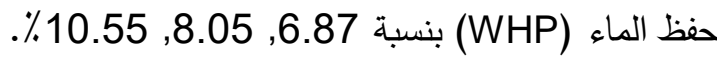
بالإضافة إلى ذلك زيادة مسام حفظ الماء WHP إلى

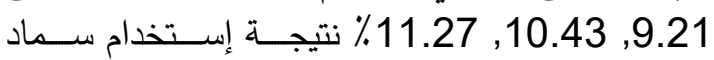
الدواجن بمعدل 5, 10, 15 طن/فدان سماد دواجن.

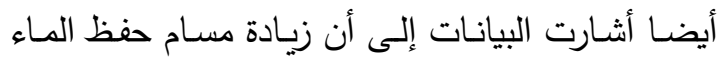

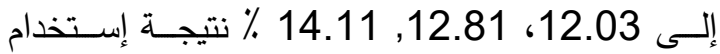

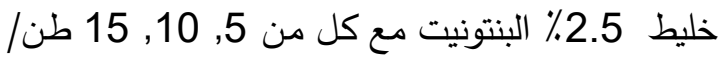

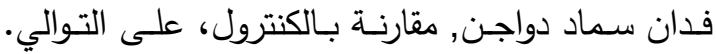

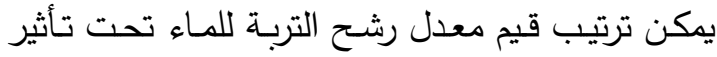

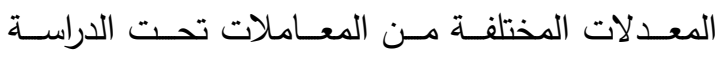
بالترتيب التالي: 2.5\% بنتونيت + 15 طن طن/فدان سماد

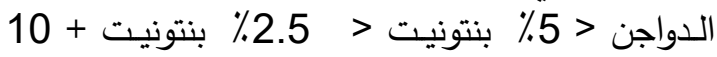

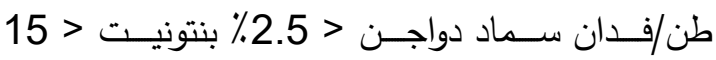

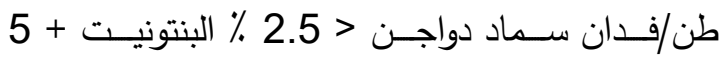

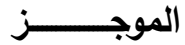

إجريت تجربـة حقلية تحت ظروف تربـة رملية

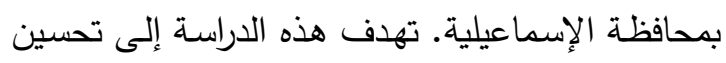

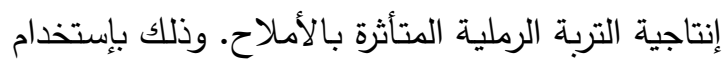

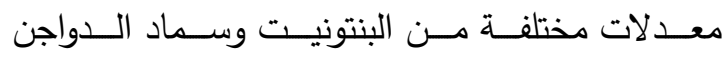

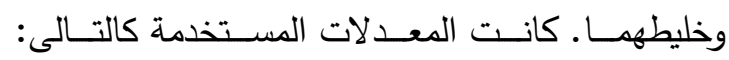
البنتونيت (1 ، 2.5 ، 5\%)، سماد الدواجن (5 , 10,

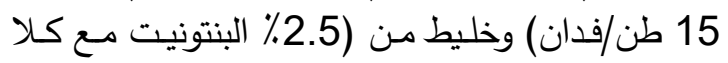

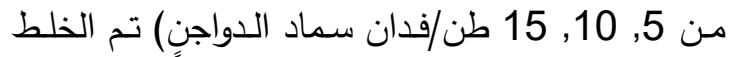

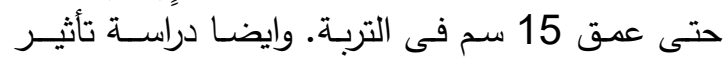

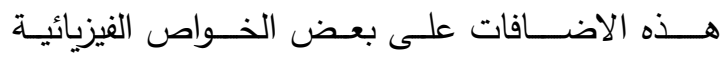

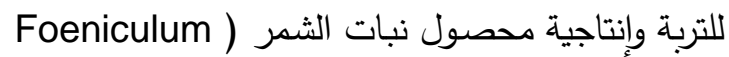
Vulgare Mill. 2018 تحت نظام الري بالتتقيط بمياه الابار ملوحتها

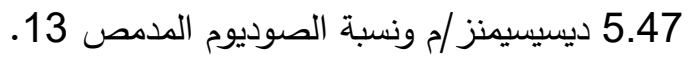

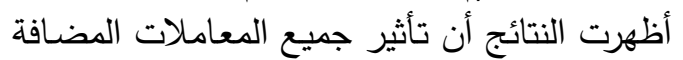

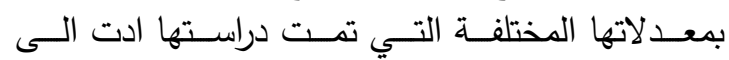

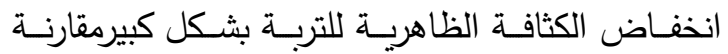

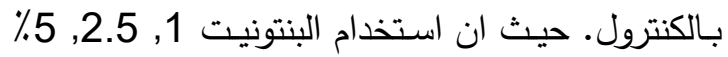
ادى إلى إنخفاض قيم الكثافة الظاهريـة بنسبة 10. 17. 4. 1.

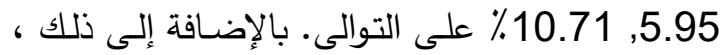

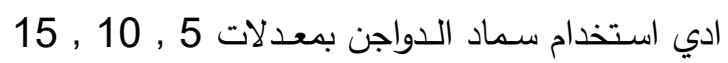

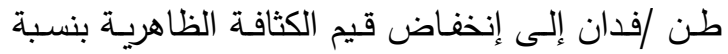

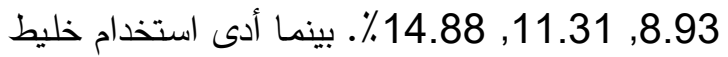

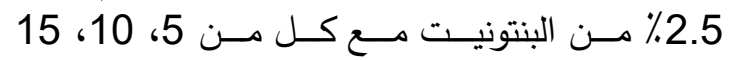

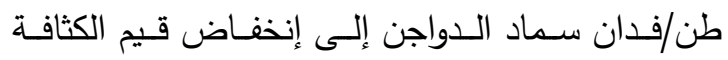




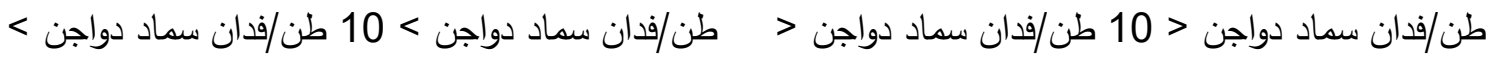

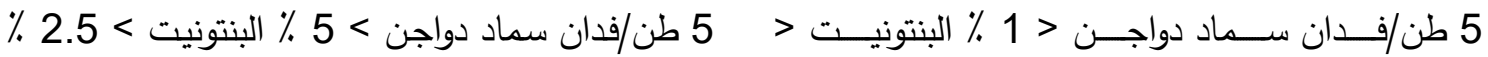

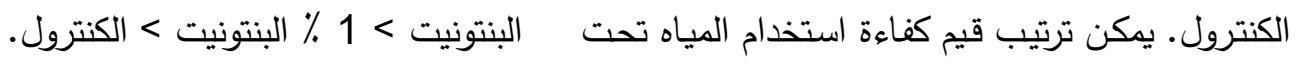

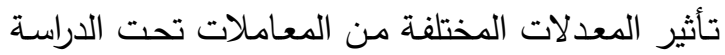

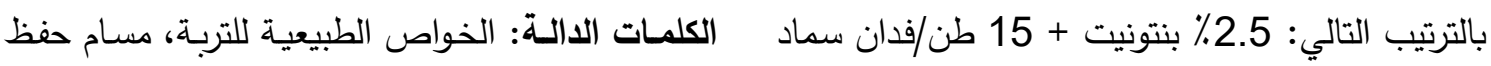

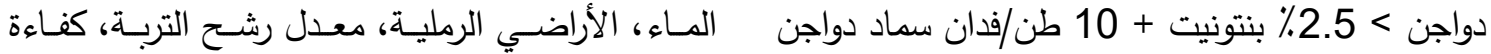

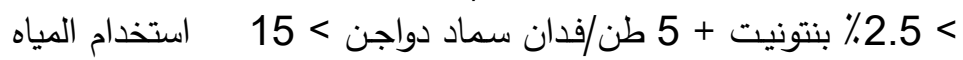

